\title{
Overexpression of PLIN5 in skeletal muscle promotes oxidative gene expression and intramyocellular lipid content without compromising insulin sensitivity.
}

Citation for published version (APA):

Bosma, M., Sparks, L. M., Hooiveld, G., Jorgensen, J., Houten, S. M., Schrauwen, P., Kersten, S., \& Hesselink, M. K. C. (2013). Overexpression of PLIN5 in skeletal muscle promotes oxidative gene expression and intramyocellular lipid content without compromising insulin sensitivity. Biochimica et Biophysica Acta-Molecular and Cell Biology of Lipids, 1831(4), 844-852.

https://doi.org/10.1016/j.bbalip.2013.01.007

Document status and date:

Published: 01/04/2013

DOI:

10.1016/j.bbalip.2013.01.007

Document Version:

Publisher's PDF, also known as Version of record

Document license:

Taverne

Please check the document version of this publication:

- A submitted manuscript is the version of the article upon submission and before peer-review. There can be important differences between the submitted version and the official published version of record.

People interested in the research are advised to contact the author for the final version of the publication, or visit the DOI to the publisher's website.

- The final author version and the galley proof are versions of the publication after peer review.

- The final published version features the final layout of the paper including the volume, issue and page numbers.

Link to publication

\footnotetext{
General rights rights.

- You may freely distribute the URL identifying the publication in the public portal. please follow below link for the End User Agreement:

www.umlib.nl/taverne-license

Take down policy

If you believe that this document breaches copyright please contact us at:

repository@maastrichtuniversity.nl

providing details and we will investigate your claim.
}

Copyright and moral rights for the publications made accessible in the public portal are retained by the authors and/or other copyright owners and it is a condition of accessing publications that users recognise and abide by the legal requirements associated with these

- Users may download and print one copy of any publication from the public portal for the purpose of private study or research.

- You may not further distribute the material or use it for any profit-making activity or commercial gain

If the publication is distributed under the terms of Article $25 \mathrm{fa}$ of the Dutch Copyright Act, indicated by the "Taverne" license above, 


\title{
Overexpression of PLIN5 in skeletal muscle promotes oxidative gene expression and intramyocellular lipid content without compromising insulin sensitivity
}

\author{
M. Bosma a, L.M. Sparks a , G.J. Hooiveld ${ }^{\text {b }}$, J.A. Jorgensen ${ }^{\text {a }}$, S.M. Houten ${ }^{\text {c }}$, P. Schrauwen ${ }^{\text {a }}$, \\ S. Kersten ${ }^{\text {b }}$, M.K.C. Hesselink ${ }^{\mathrm{d}, *}$ \\ a Department of Human Biology, NUTRIM, Maastricht University Medical Centre,+ Maastricht, The Netherlands \\ ${ }^{\mathrm{b}}$ Nutrition, Metabolism and Genomics group, Division of Human Nutrition, Wageningen University, Wageningen, The Netherlands \\ c Laboratory Genetic Metabolic Diseases, Departments of Clinical Chemistry and Pediatrics, Emma Children's Hospital, Academic Medical Center, University of Amsterdam, Amsterdam, \\ The Netherlands \\ d Department of Human Movement Sciences, NUTRIM, Maastricht University Medical Centre +, Maastricht, The Netherlands
}

\section{A R T I C L E I N F O}

Article history:

Received 16 August 2012

Received in revised form 6 January 2013

Accepted 10 January 2013

Available online 22 January 2013

\section{Keywords:}

Lipid droplet

Perilipin

OXPAT

Skeletal muscle

Insulin sensitivity

Oxidative gene expression

\begin{abstract}
A B S T R A C T
Aims/hypothesis: While lipid deposition in the skeletal muscle is considered to be involved in obesity-associated insulin resistance, neutral intramyocellular lipid (IMCL) accumulation per se does not necessarily induce insulin resistance. We previously demonstrated that overexpression of the lipid droplet coat protein perilipin 2 augments intramyocellular lipid content while improving insulin sensitivity. Another member of the perilipin family, perilipin 5 (PLIN5), is predominantly expressed in oxidative tissues like the skeletal muscle. Here we investigated the effects of PLIN5 overexpression - in comparison with the effects of PLIN2 - on skeletal muscle lipid levels, gene expression profiles and insulin sensitivity. Methods: Gene electroporation was used to overexpress PLIN5 in tibialis anterior muscle of rats fed a high fat diet. Eight days after electroporation, insulin-mediated glucose uptake in the skeletal muscle was measured by means of a hyperinsulinemic euglycemic clamp. Electron microscopy, fluorescence microscopy and lipid extractions were performed to investigate IMCL accumulation. Gene expression profiles were obtained using microarrays. Results: TAG storage and lipid droplet size increased upon PLIN5 overexpression. Despite the higher IMCL content, insulin sensitivity was not impaired and DAG and acylcarnitine levels were unaffected. In contrast to the effects of PLIN2 overexpression, microarray data analysis revealed a gene expression profile favoring FA oxidation and improved mitochondrial function. Conclusions/interpretation: Both PLIN2 and PLIN5 increase neutral IMCL content without impeding insulin-mediated glucose uptake. As opposed to the effects of PLIN2 overexpression, overexpression of PLIN5 in the skeletal muscle promoted expression of a cluster of genes under control of PPAR $\alpha$ and PGC1 $\alpha$ involved in FA catabolism and mitochondrial oxidation.
\end{abstract}

(c) 2013 Elsevier B.V. All rights reserved.

\section{Introduction}

Obesity is associated with increased lipid supply to the skeletal muscle resulting in increased intramyocellular lipid (IMCL) storage. Accumulation of IMCL is associated with the development of insulin resistance. However, IMCL accumulation per se does not necessarily induce insulin resistance (reviewed in [1]). Recent studies suggest that increasing the capacity for triacylglycerol (TAG) storage in lipid

Abbreviations: ATGL, adipose triglyceride lipase; CGI-58, comparative gene identification-58; DAG, diacylglycerol; FA, fatty acid; GO, gene ontology; GSEA, gene set enrichment analysis; IMCL, intramyocellular lipid; LD, lipid droplet; NES, normalized enrichment score; PLIN, perilipin; TA, tibialis anterior; TAG, triacylglycerol

* Corresponding author at: Department of Human Movement Sciences, NUTRIM School for Nutrition, Toxicology and Metabolism, Maastricht University Medical Centre+, 6200MD Maastricht, The Netherlands. Tel.: + 3143 3881317; fax: + 31433670972.

E-mail address: matthijs.hesselink@maastrichtuniversity.nl (M.K.C. Hesselink). droplets (LDs) creates a sink for storage of fatty acids (FAs) in the form of neutral lipids thereby sequestering FAs and protecting against lipotoxicity [2-5].

By regulating processes like LD synthesis, breakdown, fusion, intracellular transport and interorganelle interactions, LD coat proteins are determinants of the highly dynamic nature of LDs (reviewed in [6,7]). One of the major lipid droplet coat protein families characterized to date is the perilipin family. Perilipin 2 (PLIN2), PLIN3 and PLIN5 are considered the major perilipins in the skeletal muscle. Indeed, we have recently shown that PLIN2 overexpression in the muscle results in massive fat accumulation in the muscle, while insulin-mediated glucose uptake was only modestly increased [2]. Furthermore, PLIN2 overexpression also blunted high fat diet-induced induction of expression of OXPHOS protein complexes [2], which may indicate that in the long run oxidative capacity will no longer keep track with intramyocellular lipid content in this situation. 
Why the skeletal muscle expresses both PLIN2 and PLIN5 is still unknown. We and others $[8,9]$ recently found that PLIN5 not only localizes to LDs, but also to the mitochondria. Thus, the putative role of PLIN5 is most likely not limited to the regulation of lipolysis. Putatively, PLIN5 may also be involved in shuttling of FAs to the mitochondria for oxidation. In line with this we observed that PLIN5 overexpression also augmented intramyocellular $\mathrm{LD}$ content in parallel with improved oxidation of palmitate to $\mathrm{CO}_{2}$ [8]. Here, we aimed to further investigate the effects of PLIN5 overexpression - in comparison with effects of PLIN2 - on lipid storage, transcriptomic oxidative gene profiles, and insulin sensitivity.

\section{Materials and methods}

\subsection{Study design}

8-week old male Wistar rats were purchased from Charles River (Wilmington, Massachusetts, USA). Rats were housed individually on a 12:12 h light-dark cycle (light from 7:00 am to 7:00 pm), at room temperature $\left(21-22{ }^{\circ} \mathrm{C}\right)$ with ad libitum access to tap water. Rats were fed a high fat diet (45\% energy from fat, D01060502, Research Diets, New Brunswick, NJ, USA) for the duration of the 3-week intervention. The study complied with the 'Principles of laboratory animal care' (NIH publication no. 85-23, revised 1985; http://grants1.nih.gov/grants/olaw/ references/phspol.htm) and The Animal Care and Use Committee of Maastricht University approved the experiments (approval number 2010-036). During the experiments all efforts were made to minimize suffering of the animals.

\subsection{Electroporation}

Two weeks after the start of the diet, overexpression of Plin5 in either the right or left tibialis anterior (TA) muscle of the rat was accomplished by an in vivo DNA electrotransfer technique to achieve overexpression of PLIN5 in one leg; the contralateral TA served as a sham-electroporated internal control. Plin5 was electroporated randomly in the left or the right TA. DNA electroporation was performed under isoflurane anesthesia. TA muscles were transcutaneously injected with either $150 \mu \mathrm{g}(2 \mu \mathrm{g} / \mu \mathrm{l})$ pcDNA3.1-CMV-Plin5 or pcDNA3.1-empty vector in $0.9 \%$ sterile saline. Within $15 \mathrm{~s}$ after the last injection 5 electric pulses were applied by two stainless steel plate electrodes placed at the ventral and dorsal side of the leg. One high voltage pulse of $800 \mathrm{~V} / \mathrm{cm}$ and four low voltage pulses of $80 \mathrm{~V} / \mathrm{cm}$ at $1 \mathrm{~Hz}$ were generated by an ECM 830 electroporator (BTX, San Diego, CA, USA) as described previously [10,11]. Rats were killed 8 days post-electroporation. TA muscles were quickly dissected and processed for mitochondrial isolations and morphological analysis. The remainder of the TA was rapidly frozen in melting isopentane for further analyses.

\subsection{Cannulation and hyperinsulinemic euglycemic clamps}

Throughout the entire study, rats were handled daily for familiarization. Indwelling catheters were placed in the right jugular vein (for the sampling of blood) and the left carotid artery (for the infusion of insulin and glucose) under isoflurane anesthesia and aseptic conditions, two weeks before the hyperinsulinemic euglycemic clamp was performed. The venous catheter was extended to the level of the right atrium and the arterial catheter within the aortic arch. Both catheters were tunnelled subcutaneously and exteriorized at the top of the head, where they were attached in dentist cement between 2 and 3 screws onto a $90^{\circ}$-bend needle. The catheters were filled with a mixture of 85\% glycerol (Merck, Darmstadt, Germany) and $500 \mathrm{U} / \mathrm{ml}$ heparin (Leo Pharma BV, Breda, The Netherlands) to maintain patency. All rats regained pre-surgery body mass within 3 days.

Hyperinsulinemic euglycemic clamps of conscious rats were performed after a $6 \mathrm{~h}$ fast. Insulin stimulated glucose disposal in vivo within the individual tibialis anterior muscles was studied according to a previously described method [12]. A primed continuous infusion of insulin (Actrapid HM; Novo Nordisk, Copenhagen, Denmark) was administered at a rate of $13 \mathrm{mU} / \mathrm{kg} / \mathrm{min}$ for $120 \mathrm{~min}$. Blood glucose values were monitored at 10-min intervals throughout the clamp. The glucose infusion rate (GIR) was adjusted to maintain blood glucose concentration within the range of 3.5-4.5 mM. Rats were conscious during the entire clamp. 45 min before completion of the clamp, a bolus of $140 \mu \mathrm{Ci} / \mathrm{kg}$ of the non-metabolizable glucose analogue $2-\left[{ }^{3} \mathrm{H}(\mathrm{N})\right]-$ deoxy-D-glucose (Perkin Elmer, Waltham, Massachusetts, USA) was administered to measure insulin-stimulated glucose disposal in the individual TA muscles. Upon completion of the clamp, the rats were sacrificed with an overdose of sodium pentobarbital and tibialis anterior muscles were quickly dissected and frozen in liquid nitrogen-cooled isopentane and stored at $-80{ }^{\circ} \mathrm{C}$ until further analyses.

\section{4. ${ }^{3} \mathrm{H}$-deoxyglucose measurements}

Frozen TA muscle sections were ground to powder under liquid nitrogen, homogenized in MilliQ water, and eluted on columns filled with DOWEX ion-exchange resin (Sigma, St. Louis, Missouri, USA) using elution buffer $(0.3 \mathrm{M}$ ammonium acetate and $1.25 \%$ formic acid in $\mathrm{H}_{2} \mathrm{O}, \mathrm{pH}$ 4.9). Ionizing radiation counts were determined by scintillation counting.

\section{5. ${ }^{14} \mathrm{C}$-palmitate oxidation assays}

Palmitate oxidation was determined in skeletal muscle homogenates as previously described [13]. Briefly, muscle was homogenized in a buffer ( $\mathrm{pH} 7.4$ ) containing $250 \mathrm{mM}$ sucrose, $10 \mathrm{mM}$ Tris- $\mathrm{HCl}$, $2 \mathrm{mM}$ ATP and $1 \mathrm{mM}$ EDTA (Sigma, St. Louis, USA). This method does not affect mitochondrial morphology and function [14]. Subsequently, the muscle homogenates were plated in triplicate into a modified 48-well trapping device [15]. A small groove was engineered between adjacent wells so that $\mathrm{CO}_{2}$ could freely diffuse between the incubation and trap wells. Reactions were started with the addition of reaction media yielding final concentrations (in $\mathrm{mM}$ ) of 0.2 palmitate and $0.0175\left[1-{ }^{14} \mathrm{C}\right]$-palmitate and 125 sucrose, 20 Tris- $\mathrm{HCl}, 25 \mathrm{KH}_{2} \mathrm{PO}_{4}$, $200 \mathrm{KCL}, 2.5 \mathrm{MgCl}, 0.25$ malate, 4 ATP, 2.5 DTT, 2.5 carnitine, 0.125 coenzyme A, and $0.25 \mathrm{NAD}^{+}$. Palmitate was coupled to FA-free BSA in a molar ratio of 5:1. Trapping devices were sealed with a siliconized rubber gasket and incubated at $37^{\circ} \mathrm{C}$. After $2 \mathrm{~h}$, reactions were terminated in the sealed reaction plates by the addition of $70 \%$ perchloric acid to the incubation wells. Perchloric acid also results in precipitation of the remaining FAs in the media. The trapping device was transferred to an orbital shaker, and ${ }^{14} \mathrm{CO}_{2}$ was trapped in the adjoining well in $1 \mathrm{~N}$ $\mathrm{NaOH}$ for $1 \mathrm{~h}$. The acidified medium was stored at $4{ }^{\circ} \mathrm{C}$ overnight, and then acid soluble metabolites (ASMs) were assayed in supernatants of the acid precipitate. Radioactivity of $\mathrm{CO}_{2}$ and ASMs was determined by liquid scintillation counting by use of $5 \mathrm{ml}$ of Hionic Fluor (Perkin Elmer, Boston, USA). Data were normalized to protein content.

\subsection{Electron microscopy procedures}

Ultrastructural morphology was examined using transmission electron microscopy. Muscle tissue sections were fixed in $2.5 \%$ glutaraldehyde in $0.1 \mathrm{M}$ phosphate buffer ( $\mathrm{pH}$ 7.4). Postfixation was performed in $1 \%$ osmium tetroxide in $0.1 \mathrm{M}$ cacodylate buffer ( $\mathrm{pH}$ 7.4) supplemented with $1.5 \%$ potassium ferrocyanide. The samples were then dehydrated and embedded in epon. Ultrathin sections were examined using a Philips CM100 electron microscope. Electron microscopy pictures were available from 4 rats. 5-10 images per muscle sample were taken randomly. LD size was measured using the freehand selection tool of ImageJ [16]. 


\subsection{Oil-red-O staining and immunofluorescence}

Neutral lipids were stained in the muscle sections with a modified Oil-red-O staining along with immunofluorescence to study PLIN5 and laminin using antibodies against PLIN5 (\#GP31; Progen Biotechnik, Heidelberg, Germany) and laminin (L-9393; Sigma, St. Louis, USA) as previously described [17] and visualized with appropriate secondary Alexafluor conjugated antibodies (Invitrogen, Groningen, The Netherlands).

\subsection{Lipid profiles}

Intramyocellular TAG levels were measured using the method of Schwartz and Wolins [18]. DAG [2] and acylcarnitine [19] levels were measured as described previously.

\subsection{Western blots}

Western blots were performed with muscle homogenates in RIPAlysis buffer mixed 1:1 with Laemmli sample buffer (Bio-Rad, Mississauga, Ontario, Canada) using antibodies directed against PLIN2 (GP40; Progen, Heidelberg, Germany), PLIN3 (SC-14726, Santa Cruz Biotechnology, Heidelberg, Germany), PLIN5 (GP31; Progen, Heidelberg, Germany), ATGL (2138, Cell Signaling, Boston, USA), CGI-58 (NB110-41576, Novus Biologicals, Littleton, USA), and HSL (4107, Cell Signaling, Boston, USA). Secondary antibodies for PLIN2, PLIN3 PLIN5, ATGL and SR-actin contained a fluorescent tag (IRDye800- or IRDye700-conjugated secondary antibodies (Rockland, Tebu-bio, Heerhugowaard, The Netherlands, and LICOR Biosciences, Westburg, Leusden, The Netherlands). Protein quantification was performed by scanning on an Odyssey Infrared Imaging system (LI-COR Biotechnology, Lincoln, Nebraska, USA). CGI-58 and HSL were detected using an HRP-conjugated antibody and ECL detection. Protein expression values were standardized against sr-actin protein expression (Sigma, St. Louis, USA) and expressed in arbitrary units (AU).

\subsection{RNA isolation and microarray gene expression analysis}

Total RNA from rat tibialis anterior muscle was extracted and purified with the RNeasy kit for fibrous tissue (Qiagen, Venlo, The Netherlands). RNA quality was assessed on an Agilent 2100 bioanalyzer (Agilent Technologies, Amsterdam, The Netherlands) with 6000 Nano Chips using the Eukaryote Total RNA Nano assay. RNA was judged as suitable for array hybridization only if samples showed intact bands corresponding to the $28 \mathrm{~S}$ and $18 \mathrm{~S}$ rRNA subunits, displayed no chromosomal peaks or RNA degradation products, and had a RIN (RNA integrity number) above 8.0. RNA samples from 6 rats were pooled. Five micrograms of RNA were used for one cycle cRNA synthesis (Affymetrix, Santa Clara, CA). Hybridization, washing and scanning of Affymetrix rat arrays was carried out according to standard Affymetrix protocols. To adjust for non-specific hybridization and optical noise, the array expression data were normalized with RMA (robust multichip analysis, a package of the Bioconductor project [20] in the R environment. Functional analysis of the array data was performed by a method based on enrichment of gene sets (Gene Ontology (GO) classes using the application GSEA [21] and gene set clustering analysis using Cytoscape [22].
A
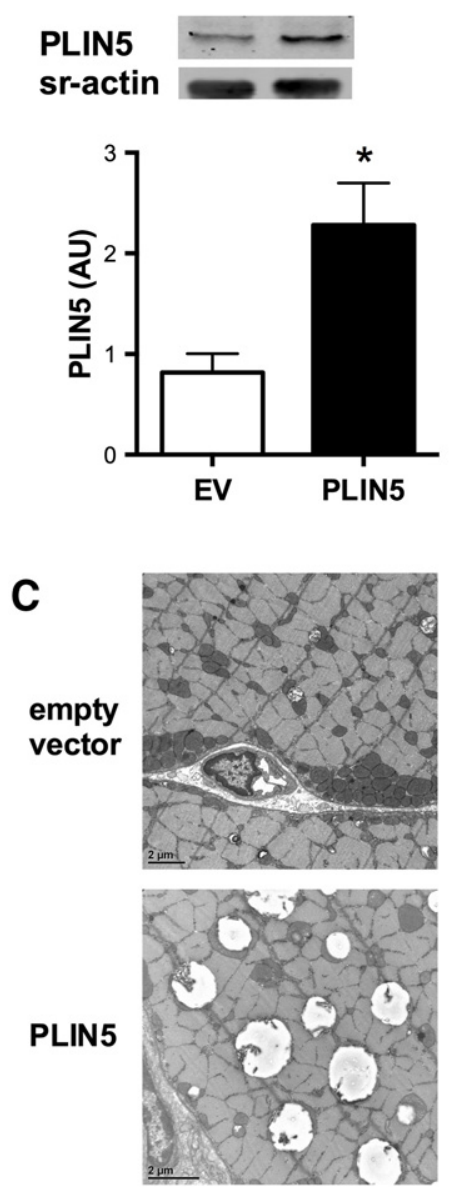

B
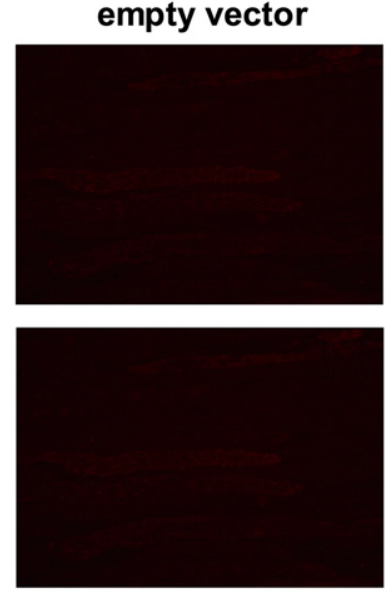

D
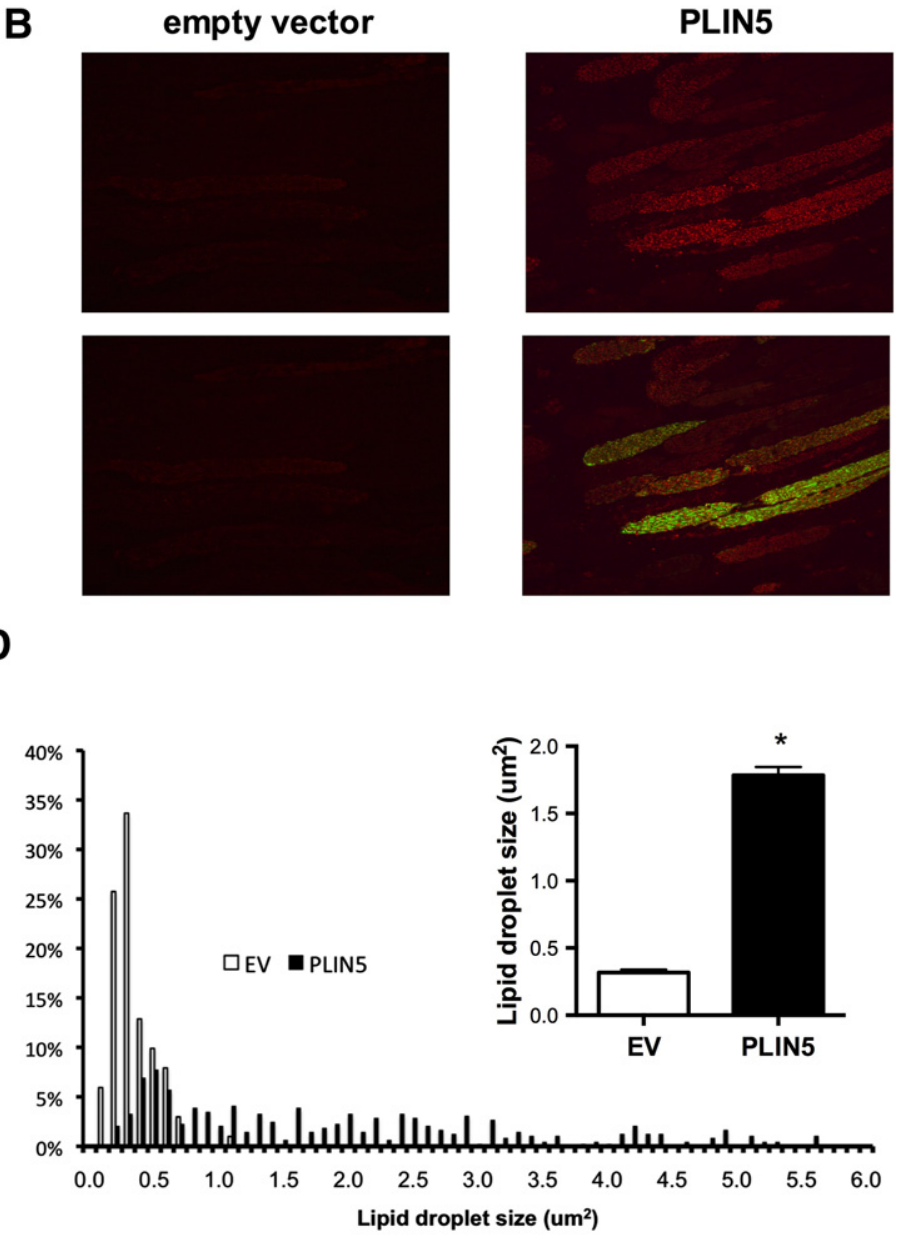

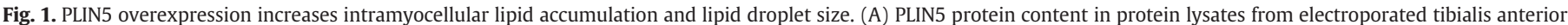

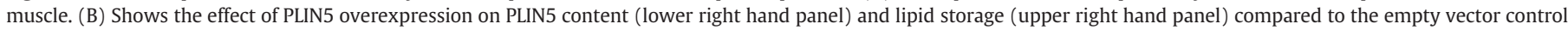

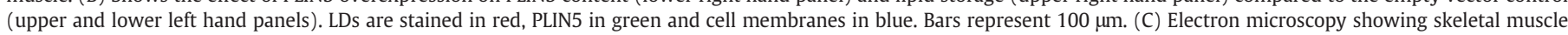
ultrastructure. (D) Lipid droplet size distribution and average LD size. EV: empty vector, ${ }^{*} \mathrm{P}<0.05$, error bars represent $\mathrm{SEM}$. 
Microarray data have been submitted to Gene Expression Omnibus (GEO number pending).

\subsection{Statistical analysis}

Results are presented as mean \pm SEM. Differences between groups were evaluated with paired T-tests. Outcomes were considered statistically significant when $\mathrm{P}<0.05$ (two-tailed). Analyses were performed using the Statistical Package for the Social Sciences (SPSS 16.0, Nieuwegein, The Netherlands) software for Mac 16.0. For microarray data, normalized enrichment scores (NES) and false discovery rates (q-values), calculated by the application GSEA, were reported. Q-values $<0.05$ were considered statistically significant. In Cytoscape, cut-off values were set at $\mathrm{P}<0.005$ and $\mathrm{q}<0.1$.

\section{Results}

\subsection{PLIN5 overexpression increases intramyocellular lipid storage}

PLIN5 electroporation resulted in a 2.8-fold overexpression of PLIN5 (empty vector muscle lysates $0.81 \pm 0.19$, PLIN5 muscle $2.28 \pm 0.42 \mathrm{AU}, \mathrm{P}<0.05, \mathrm{n}=9$ ) (Fig. 1A). The overexpression of PLIN5 gave rise to a pronounced increase in IMCL levels (Fig. 1B-C). Lipid droplet size was increased; the LD size distribution shifted from LDs of up to $1.2 \mu \mathrm{m}^{2}$ in size in the empty vector-electroporated muscle fibers to LDs of up to $5.8 \mu \mathrm{m}^{2}$ in the PLIN5 overexpressing fibers (Fig. 1D). The average LD size increased more than five-fold $(\mathrm{P}<0.01)$ (Fig. 1D). The increase in LD size occurred in parallel with a 3-fold increase in intramyocellular triacylglycerol (TAG) levels (Fig. 2A). Diacylglycerol (DAG) levels (Fig. 2B) were unchanged. Acylcarnitines are formed in mitochondria when $\beta$-oxidation rates outpace the capacity of the TCA cycle [23] and have been implemented in development of insulin resistance. Free carnitine (Fig. 2C) and acylcarnitine levels (Fig. 2D) were not different in the PLIN5-electroporated muscle versus the empty vector control. Additionally, the FA-composition of the DAG fraction was not significantly changed and the individual acylcarnitine
A

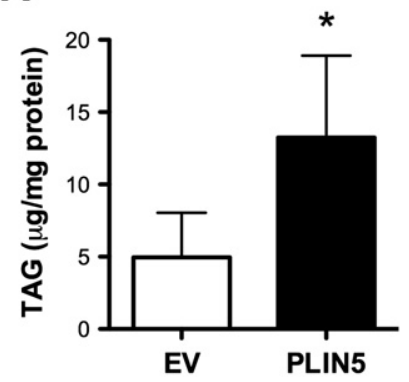

C

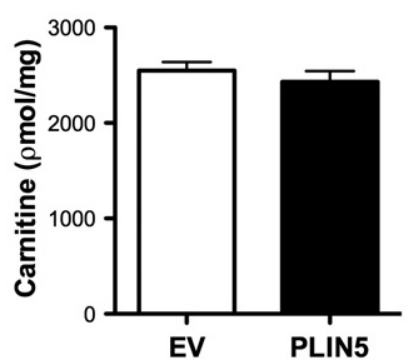

B

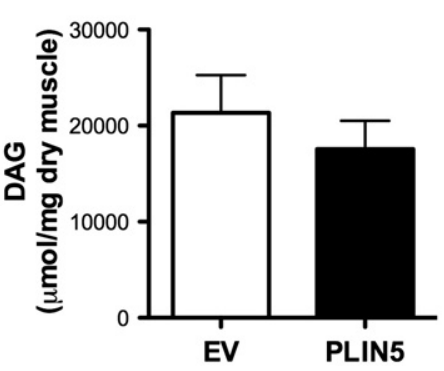

D

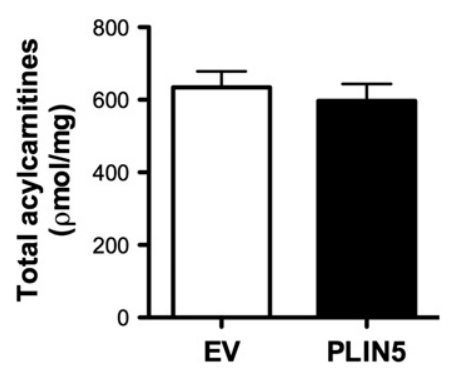

Fig. 2. PLIN5 overexpression results in increased TAG accumulation. (A) Skeletal muscle TAG levels (ug/mg protein). (B) DAG content ( $\mu \mathrm{mol} / \mathrm{mg}$ dry weight). (C) Free carnitine ( $\rho \mathrm{mol} / \mathrm{mg}$ protein). (D) Acylcarnitine levels ( $\rho \mathrm{mol} / \mathrm{mg}$ protein). EV: empty vector, ${ }^{*} \mathrm{P}<0.05$, error bars represent SEM. species did not show a different profile in empty-vector versus PLIN5electroporated muscles (Supplemental Tables S1 and S2, respectively).

\subsection{Increased ATGL protein content in PLIN5 overexpressing muscle}

PLIN5 overexpression was not paralleled by compensatory changes in PLIN2 and PLIN3 protein content (Fig. 3A and B). ATGL protein content was significantly increased by $16 \%(P=0.047)$ (Fig. $3 C)$, while CGI-58 protein content showed a trend towards downregulation $(P=0.10)$ (Fig. 3D). HSL protein content was similar in empty vector and PLIN5-electroporated muscle (Fig. 3E).

\subsection{PLIN5 overexpression results in a gene expression pattern favoring} FA oxidative metabolism

Upon PLIN5 overexpression, 775 genes were upregulated, 1042 genes were downregulated (fold change cut-off value 1.3 ). Table 1 gives the gene expression profiles for a selection of genes, the complete microarray dataset can be found as supporting document online (Supplemental Table S3, GEO accession number: GSE43832). Gene class enrichment analyses revealed that PLIN5 overexpression resulted in increased expression of genes involved in FA $\beta$-oxidation, the TCA cycle, the electron transport chain and mitochondrion organization (Table 2). Genes involved in immune processes were downregulated (Table 3). To investigate if these gene expression profiles were specific
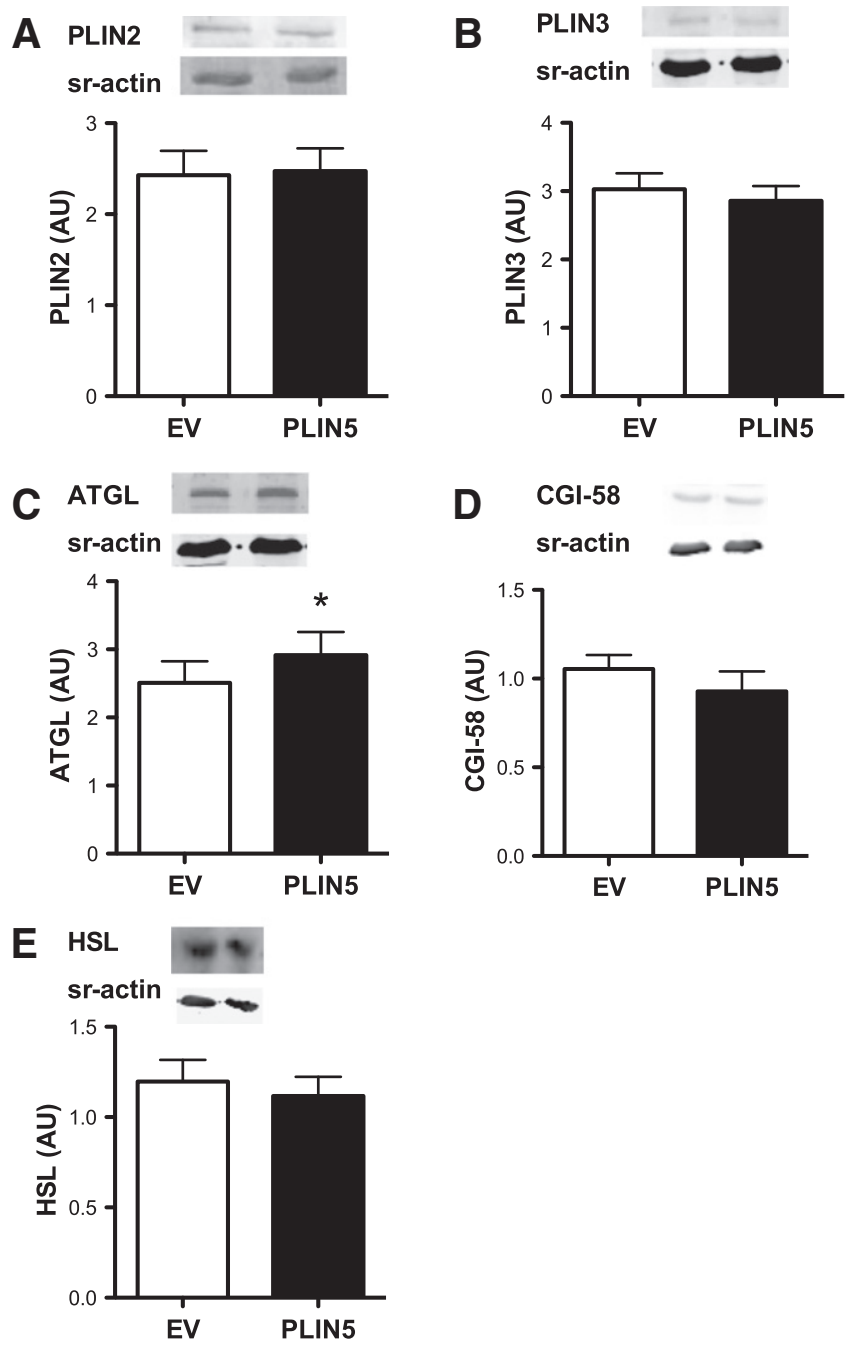

Fig. 3. PLIN5 overexpression increased ATGL protein content. (A-D) Western blots for PLIN2 (A), PLIN3 (B), ATGL (C), CGI-58 (D) and HSL (E) in whole muscle protein lysates $(n=17)$. 
Table 1

Heat map. Fold changes in gene expression for a selection of genes are given for PLIN5 versus empty-vector electroporated muscles.

\begin{tabular}{|c|c|c|c|}
\hline Gene name & Entrez ID & Description & Fold change PLIN5 vs EV \\
\hline Pla2g4c & 691810 & Phospholipase A2, group IVC (cytosolic, calcium-independent) & 2.94 \\
\hline Acsm5 & 361637 & Acyl-CoA synthetase medium-chain family member 5 & 2.17 \\
\hline Scand3 & 288622 & SCAN domain containing 3 & 2.17 \\
\hline LOC679586 & 679586 & Similar to ATP synthase, $\mathrm{H}+$ transporting, mitochondrial F0 complex, subunit $\mathrm{G}$ & 1.89 \\
\hline Atp5hl1 & 306478 & ATP synthase, $\mathrm{H}+$ transporting, mitochondrial F0 complex, subunit d-like 1 & 1.78 \\
\hline Dync2li1 & 298767 & Dynein cytoplasmic 2 light intermediate chain 1 & 1.77 \\
\hline Acat3 & 308100 & Acetyl-Coenzyme A acetyltransferase 3 & 1.70 \\
\hline Rfk & 499328 & Riboflavin kinase & 1.70 \\
\hline Angptl4 & 362850 & Angiopoietin-like 4 & 1.68 \\
\hline Atp6v1a & 685232 & ATPase, $\mathrm{H}+$ transporting, lysosomal V1 subunit $\mathrm{A}$ & 1.63 \\
\hline Hsd3b & 682974 & 3 beta-hydroxysteroid dehydrogenase/delta-5-delta- 4 isomerase type II & 1.59 \\
\hline Fabp4 & 79451 & Fatty acid binding protein 4 & 1.58 \\
\hline Acot3 & 314304 & Acyl-CoA thioesterase 3 & 1.57 \\
\hline Acnat1 & 681043 & Acyl-coenzyme A amino acid N-acyltransferase 1 & 1.55 \\
\hline LOC689271 & 689271 & Similar to ATP synthase, $\mathrm{H}+$ transporting, mitochondrial $\mathrm{F} 0$ complex, subunit $\mathrm{f}$, isoform 2 & 1.54 \\
\hline RGD1559672 & 500650 & Similar to Translocase of inner mitochondrial membrane 23 homolog & 1.48 \\
\hline Nkain3 & 689576 & $\mathrm{Na}+/ \mathrm{K}+$ transporting ATPase interacting 3 & 1.47 \\
\hline Ehhadh & 171142 & Enoyl-Coenzyme A, hydratase/3-hydroxyacyl Coenzyme A dehydrogenase & 1.45 \\
\hline Atp6v1b1 & 312488 & ATPase, $\mathrm{H}$ transporting, lysosomal V1 subunit B1 & 1.41 \\
\hline Atp6v1g3 & 289407 & ATPase, $\mathrm{H}+$ transporting, lysosomal V1 subunit G3 & 1.38 \\
\hline Fads6 & 303671 & Fatty acid desaturase domain family, member 6 & 1.35 \\
\hline Mrps27 & 361883 & Mitochondrial ribosomal protein S27 & 1.34 \\
\hline Acox 2 & 252898 & Acyl-Coenzyme A oxidase 2 , branched chain & 1.33 \\
\hline RGD1561341 & 502769 & Similar to translocase of outer mitochondrial membrane 20 homolog & 1.33 \\
\hline Pld6 & 287366 & Phospholipase D family, member 6 & 1.33 \\
\hline Atp5s & 362749 & ATP synthase, $\mathrm{H}+$ transporting, mitochondrial F0 complex, subunit s (factor B) & 1.32 \\
\hline Slc27a3 & 295219 & Solute carrier family 27 (fatty acid transporter), member 3 & -2.98 \\
\hline Pparg & 25664 & Peroxisome proliferator-activated receptor gamma & -1.89 \\
\hline Gk5 & 367146 & Glycerol kinase 5 (putative) & -1.79 \\
\hline Ppt1 & 29411 & Palmitoyl-protein thioesterase 1 & -1.70 \\
\hline $\operatorname{Sln}$ & 367086 & Sarcolipin & -1.68 \\
\hline Pla2g2a & 29692 & Phospholipase A2, group IIA (platelets, synovial fluid) & -1.66 \\
\hline Smpd3 & 94338 & Sphingomyelin phosphodiesterase 3 , neutral membrane & -1.56 \\
\hline Pltp & 296371 & Phospholipid transfer protein & -1.45 \\
\hline Slc37a2 & 500973 & Solute carrier family 37 (glycerol-3-phosphate transporter), member 2 & -1.38 \\
\hline Chn2 & 84031 & Chimerin (chimaerin) 2 & -1.38 \\
\hline Prkcd & 170538 & Protein kinase C, delta & -1.35 \\
\hline Ldhal6b & 369018 & Lactate dehydrogenase A-like 6B & -1.35 \\
\hline Scd & 83792 & Stearoyl-CoA desaturase (delta-9-desaturase) & -1.31 \\
\hline
\end{tabular}

for PLIN5-induced lipid accumulation, we compared these results with overexpression of PLIN2. As described previously [2], PLIN2 overexpression increased IMCL levels concurrent with a gene expression profile favoring lipid storage rather than oxidation. Fig. 4 displays the effects of PLIN5 and PLIN2 electroporation (versus the corresponding empty vector controls) on gene sets involved in fatty acid oxidation and mitochondrial function. Interestingly, PLIN5 has opposite effects on transcription levels of genes involved in FA oxidation compared to PLIN2. Our data indicate that - as opposed to PLIN2 overexpression - PLIN5 overexpression is associated with induction of a transcriptional program favoring FA catabolism and subsequent mitochondrial oxidation. These changes in gene expression were functionally reflected in increased ${ }^{14} \mathrm{C}$-palmitate oxidation to $\mathrm{CO}_{2}$ after PLIN5 overexpression which we observed previously (empty vector $0.05 \pm 0.008$, PLIN5 $0.07 \pm 0.012$ ${ }^{14} \mathrm{CO}_{2} /$ total ${ }^{14} \mathrm{C}$-palmitate oxidation, $P=0.05$ ) [8].

\subsection{Despite increased IMCL content, PLIN5 overexpression did not impair insulin sensitivity}

Skeletal muscle insulin sensitivity was measured under stable clamp conditions (Supplemental Fig. 1). Despite the pronounced effect of PLIN5 overexpression on intramyocellular lipid storage and LD size, ${ }^{3} \mathrm{H}$-deoxyglucose uptake was similar in empty vector and PLIN5-electroporated muscle (Fig. 5), indicating that PLIN5-induced intramyocellular lipid storage did not impair insulin mediated glucose uptake.

\section{Discussion}

Elevated IMCL levels have been associated with the development of insulin resistance [24-26], however data from the last decade indicates that the relation between IMCL and insulin sensitivity may be less straightforward than originally proposed [3,4,27]. In recent years, PLINs have been identified as important regulators of skeletal muscle lipid metabolism. Skeletal muscle-specific PLIN2 overexpression improved insulin sensitivity despite increased IMCL levels [2]. Here we show that the augmented IMCL storage as a result of PLIN5 electroporation did not impair insulin-stimulated glucose uptake, consistent with effects of PLIN2 overexpression. Yet, in striking contrast to the effects of PLIN2 overexpression [2], PLIN5 electroporation resulted in a gene expression profile favoring fatty acid catabolism and mitochondrial function. This profile of high PLIN5 levels, augmented IMCL storage, increased oxidative gene expression and fat oxidative capacity without a negative impact on skeletal muscle insulin-mediated glucose uptake mimics observations in master athletes [28].

Both PLIN2 and PLIN5 overexpression resulted in increased LD size, consistent with in vitro studies $[9,29,30]$. When compared to PLIN2induced LD expansion [2], LDs in PLIN5-overexpressing muscle were approximately 1.3 -fold larger in size. While large LDs have previously been suggested to be more detrimental with respect to insulin sensitivity than small LDs [31-33], we here demonstrate that augmenting LD size by overexpressing PLIN5 did not impede insulin-mediated glucose uptake or compromise mitochondrial function measured as fat oxidative capacity within the time frame of our studies. 
Table 2

PLIN5 overexpression increased expression of genes involved in mitochondrial function and fatty acid oxidation. Microarray gene expression profiles for PLIN5 overexpression were clustered in Gene Ontology (GO) classes using GSEA (Gene Set Enrichment Analysis). This table shows the GO classes that were enriched in the set of upregulated genes. All upregulated GO classes with a false discovery rate (FDR) q-value $<0.05$ are shown. NES: normalized enrichment score.

\begin{tabular}{|c|c|c|c|c|}
\hline GO & Name & $\begin{array}{l}\text { Number of } \\
\text { genes in the } \\
\text { gene set }\end{array}$ & NES & $\begin{array}{l}\text { FDR } \\
\text { q-value }\end{array}$ \\
\hline GO:0005759 & Mitochondrial matrix & 164 & 4.01 & $<1.00 \mathrm{E}-06$ \\
\hline GO:0044455 & Mitochondrial membrane part & 103 & 3.60 & $<1.00 \mathrm{E}-06$ \\
\hline GO:0045333 & Cellular respiration & 60 & 3.59 & $<1.00 \mathrm{E}-06$ \\
\hline GO:0005743 & Mitochondrial inner membrane & 266 & 3.50 & $<1.00 \mathrm{E}-06$ \\
\hline GO:0019866 & Organelle inner membrane & 288 & 3.30 & $<1.00 \mathrm{E}-06$ \\
\hline GO:0030964 & NADH dehydrogenase complex & 31 & 3.29 & $<1.00 \mathrm{E}-06$ \\
\hline GO:0045271 & Respiratory chain complex I & 31 & 3.28 & $<1.00 \mathrm{E}-06$ \\
\hline GO:0005747 & $\begin{array}{l}\text { Mitochondrial respiratory chain } \\
\text { complex I }\end{array}$ & 31 & 3.26 & $<1.00 \mathrm{E}-06$ \\
\hline GO:0005746 & Mitochondrial respiratory chain & 46 & 3.01 & $<1.00 \mathrm{E}-06$ \\
\hline GO:0022900 & Electron transport chain & 60 & 2.98 & $<1.00 \mathrm{E}-06$ \\
\hline GO:0070469 & Respiratory chain & 49 & 2.90 & $4.52 \mathrm{E}-05$ \\
\hline GO:0006084 & Acetyl-CoA metabolic process & 45 & 2.88 & $1.29 \mathrm{E}-04$ \\
\hline GO:0072329 & $\begin{array}{l}\text { Monocarboxylic acid catabolic } \\
\text { process }\end{array}$ & 54 & 2.79 & $2.74 \mathrm{E}-04$ \\
\hline GO:0006091 & $\begin{array}{l}\text { Generation of precursor } \\
\text { metabolites and energy }\end{array}$ & 204 & 2.76 & $4.48 \mathrm{E}-04$ \\
\hline GO:0009060 & Aerobic respiration & 25 & 2.74 & $5.01 \mathrm{E}-04$ \\
\hline GO:0015980 & $\begin{array}{l}\text { Energy derivation by oxidation of } \\
\text { organic compounds }\end{array}$ & 117 & 2.71 & $6.28 \mathrm{E}-04$ \\
\hline GO:0022904 & $\begin{array}{l}\text { Respiratory electron transport } \\
\text { chain }\end{array}$ & 27 & 2.67 & $1.04 \mathrm{E}-03$ \\
\hline GO:0009062 & Fatty acid catabolic process & 52 & 2.58 & 2.97E-03 \\
\hline GO:0046356 & Acetyl-CoA catabolic process & 22 & 2.55 & $3.86 \mathrm{E}-03$ \\
\hline GO:0006119 & Oxidative phosphorylation & 23 & 2.48 & 7.09E-03 \\
\hline GO:0046395 & Carboxylic acid catabolic process & 120 & 2.46 & $7.23 \mathrm{E}-03$ \\
\hline GO:0003954 & NADH dehydrogenase activity & 19 & 2.43 & $8.80 \mathrm{E}-03$ \\
\hline GO:0016054 & Organic acid catabolic process & 120 & 2.42 & $9.12 \mathrm{E}-03$ \\
\hline GO:0048037 & Cofactor binding & 251 & 2.42 & $9.01 \mathrm{E}-03$ \\
\hline GO:0007005 & $\begin{array}{l}\text { Mitochondrion organization and } \\
\text { biogenesis }\end{array}$ & 125 & 2.40 & $1.01 \mathrm{E}-02$ \\
\hline GO:0050662 & Coenzyme binding & 183 & 2.39 & $1.08 \mathrm{E}-02$ \\
\hline GO:0006099 & Tricarboxylic acid cycle & 21 & 2.39 & $1.08 \mathrm{E}-02$ \\
\hline GO:0051187 & Cofactor catabolic process & 30 & 2.38 & $1.10 \mathrm{E}-02$ \\
\hline GO:0051186 & Cofactor metabolic process & 199 & 2.37 & $1.20 \mathrm{E}-02$ \\
\hline GO:0006732 & Coenzyme metabolic process & 158 & 2.37 & $1.18 \mathrm{E}-02$ \\
\hline GO:0006637 & Acyl-CoA metabolic process & 21 & 2.37 & $1.16 \mathrm{E}-02$ \\
\hline GO:0009109 & Coenzyme catabolic process & 25 & 2.34 & $1.55 \mathrm{E}-02$ \\
\hline GO:0016655 & $\begin{array}{l}\text { Oxidoreductase activity, acting on } \\
\text { NADH or NADPH, quinone or } \\
\text { similar compound as acceptor }\end{array}$ & 21 & 2.32 & $1.70 \mathrm{E}-02$ \\
\hline GO:0051262 & Protein tetramerization & 62 & 2.32 & 1.77E-02 \\
\hline GO:0035383 & Thioester metabolic process & 21 & 2.32 & $1.76 \mathrm{E}-02$ \\
\hline GO:0008137 & $\begin{array}{l}\text { NADH dehydrogenase } \\
\text { (ubiquinone) activity }\end{array}$ & 18 & 2.31 & $1.76 \mathrm{E}-02$ \\
\hline GO:0042773 & $\begin{array}{l}\text { ATP synthesis coupled electron } \\
\text { transport }\end{array}$ & 18 & 2.29 & $2.11 \mathrm{E}-02$ \\
\hline GO:0050136 & $\begin{array}{l}\text { NADH dehydrogenase (quinone) } \\
\text { activity }\end{array}$ & 18 & 2.29 & $2.11 \mathrm{E}-02$ \\
\hline GO:0016651 & Oxidoreductase activity & 53 & 2.27 & 2.27E-02 \\
\hline GO:0051087 & Chaperone binding & 33 & 2.27 & $2.23 \mathrm{E}-02$ \\
\hline GO:0019395 & Fatty acid oxidation & 72 & 2.24 & $2.84 \mathrm{E}-02$ \\
\hline GO:0006635 & Fatty acid beta-oxidation & 39 & 2.23 & $3.02 \mathrm{E}-02$ \\
\hline GO:0034440 & Lipid oxidation & 73 & 2.23 & 3.09E-02 \\
\hline GO:0016469 & $\begin{array}{l}\text { Proton-transporting two-sector } \\
\text { ATPase complex }\end{array}$ & 48 & 2.22 & $3.16 \mathrm{E}-02$ \\
\hline GO:0005777 & Peroxisome & 85 & 2.21 & 3.39E-02 \\
\hline GO:0042579 & Microbody & 85 & 2.19 & $3.74 \mathrm{E}-02$ \\
\hline GO:0015985 & $\begin{array}{l}\text { Energy coupled proton transport, } \\
\text { down electrochemical gradient }\end{array}$ & 42 & 2.19 & $3.96 \mathrm{E}-02$ \\
\hline GO:0015986 & $\begin{array}{l}\text { ATP synthesis coupled proton } \\
\text { transport }\end{array}$ & 42 & 2.18 & 4.24E-02 \\
\hline GO:0006818 & Hydrogen transport & 74 & 2.17 & $4.52 \mathrm{E}-02$ \\
\hline GO:0000062 & Fatty-acyl-CoA binding & 19 & 2.16 & 4.49E-02 \\
\hline GO:0031968 & Organelle outer membrane & 88 & 2.16 & $4.54 \mathrm{E}-02$ \\
\hline
\end{tabular}

Table 3

PLIN5 overexpression lowers expression of genes involved in immune processes. Microarray gene expression profiles for PLIN5 overexpression were clustered in Gene Ontology (GO) classes using GSEA (Gene Set Enrichment Analysis). This table shows the GO classes that were enriched in the set of downregulated genes. All downregulated GO classes with a false discovery rate (FDR) q-value $<0.05$ are shown. NES: normalized enrichment score.

\begin{tabular}{|c|c|c|c|c|}
\hline GO & Name & $\begin{array}{l}\text { Number of } \\
\text { genes in the } \\
\text { gene set }\end{array}$ & NES & $\begin{array}{l}\text { FDR } \\
\text { q-val }\end{array}$ \\
\hline GO:0002252 & Immune effector process & 249 & -2.99 & $1.60 \mathrm{E}-03$ \\
\hline GO:0004428 & $\begin{array}{l}\text { Inositol or phosphatidylinositol } \\
\text { kinase activity }\end{array}$ & 31 & -2.97 & $1.15 \mathrm{E}-03$ \\
\hline GO:0002768 & $\begin{array}{l}\text { Immune response-regulating cell } \\
\text { surface receptor signaling } \\
\text { pathway }\end{array}$ & 66 & -2.94 & $1.40 \mathrm{E}-03$ \\
\hline GO:0002429 & $\begin{array}{l}\text { Immune response-activating cell } \\
\text { surface receptor signaling } \\
\text { pathway }\end{array}$ & 63 & -2.92 & $1.41 \mathrm{E}-03$ \\
\hline GO:0002274 & Myeloid leukocyte activation & 78 & -2.83 & $2.03 \mathrm{E}-03$ \\
\hline GO:0005765 & Lysosomal membrane & 61 & -2.82 & $1.99 \mathrm{E}-03$ \\
\hline GO:0016050 & Vesicle organization & 74 & -2.80 & $2.03 \mathrm{E}-03$ \\
\hline GO:0009897 & $\begin{array}{l}\text { External side of plasma } \\
\text { membrane }\end{array}$ & 177 & -2.68 & $5.10 \mathrm{E}-03$ \\
\hline GO:0000323 & Lytic vacuole & 189 & -2.61 & 7.09E-03 \\
\hline GO:0002443 & Leukocyte mediated immunity & 146 & -2.52 & $1.18 \mathrm{E}-02$ \\
\hline GO:0005096 & GTPase activator activity & 138 & -2.51 & $1.25 \mathrm{E}-02$ \\
\hline GO:0050776 & Regulation of immune response & 297 & -2.49 & $1.34 \mathrm{E}-02$ \\
\hline GO:0046488 & $\begin{array}{l}\text { Phosphatidylinositol metabolic } \\
\text { process }\end{array}$ & 72 & -2.49 & $1.29 \mathrm{E}-02$ \\
\hline GO:0005100 & Rho GTPase activator activity & 22 & -2.47 & $1.41 \mathrm{E}-02$ \\
\hline GO:0002449 & Lymphocyte mediated immunity & 118 & -2.47 & $1.36 \mathrm{E}-02$ \\
\hline GO:0046649 & Lymphocyte activation & 310 & -2.47 & $1.32 \mathrm{E}-02$ \\
\hline GO:0042110 & $\mathrm{T}$ cell activation & 212 & -2.46 & $1.32 \mathrm{E}-02$ \\
\hline GO:0005764 & Lysosome & 188 & -2.44 & $1.44 \mathrm{E}-02$ \\
\hline GO:0001727 & Lipid kinase activity & 26 & -2.39 & $1.91 \mathrm{E}-02$ \\
\hline GO:0035586 & Purinergic receptor activity & 31 & -2.39 & $1.93 \mathrm{E}-02$ \\
\hline GO:0050852 & $\mathrm{T}$ cell receptor signaling pathway & 34 & -2.32 & $2.43 \mathrm{E}-02$ \\
\hline GO:0046854 & $\begin{array}{l}\text { Phosphatidylinositol } \\
\text { phosphorylation }\end{array}$ & 15 & -2.32 & $2.38 \mathrm{E}-02$ \\
\hline G0:0006909 & Phagocytosis & 64 & -2.32 & $2.36 \mathrm{E}-02$ \\
\hline GO:0050851 & $\begin{array}{l}\text { Antigen receptor-mediated sig- } \\
\text { naling pathway }\end{array}$ & 54 & -2.32 & $2.35 \mathrm{E}-02$ \\
\hline GO:0006044 & $\begin{array}{l}\mathrm{N} \text {-acetylglucosamine metabolic } \\
\text { process }\end{array}$ & 16 & -2.28 & $2.68 \mathrm{E}-02$ \\
\hline GO:0044420 & Extracellular matrix part & 103 & -2.27 & $2.70 \mathrm{E}-02$ \\
\hline GO:0045058 & $\mathrm{T}$ cell selection & 21 & -2.25 & $2.85 \mathrm{E}-02$ \\
\hline GO:0002460 & $\begin{array}{l}\text { Adaptive immune response } \\
\text { based on somatic recombination } \\
\text { of immune receptors built from } \\
\text { immunoglobulin superfamily } \\
\text { domains }\end{array}$ & 121 & -2.24 & $2.86 \mathrm{E}-02$ \\
\hline GO:0019724 & B cell mediated immunity & 68 & -2.23 & 3.17E-02 \\
\hline GO:0001614 & $\begin{array}{l}\text { Purinergic nucleotide receptor } \\
\text { activity }\end{array}$ & 27 & -2.22 & $3.13 \mathrm{E}-02$ \\
\hline GO:0046633 & Alpha-beta T cell proliferation & 20 & -2.21 & 3.23E-02 \\
\hline GO:0006041 & Glucosamine metabolic process & 16 & -2.20 & $3.28 \mathrm{E}-02$ \\
\hline GO:0016502 & Nucleotide receptor activity & 27 & -2.19 & $3.48 \mathrm{E}-02$ \\
\hline GO:0010717 & $\begin{array}{l}\text { Regulation of epithelial to } \\
\text { mesenchymal transition }\end{array}$ & 24 & -2.17 & $3.85 \mathrm{E}-02$ \\
\hline GO:0002250 & Adaptive immune response & 124 & -2.16 & $3.85 \mathrm{E}-02$ \\
\hline GO:0007173 & $\begin{array}{l}\text { Epidermal growth factor receptor } \\
\text { signaling pathway }\end{array}$ & 39 & -2.15 & $4.24 \mathrm{E}-02$ \\
\hline GO:0005581 & Collagen & 24 & -2.14 & $4.24 \mathrm{E}-02$ \\
\hline GO:0000139 & Golgi membrane & 265 & -2.14 & 4.19E-02 \\
\hline GO:0050778 & $\begin{array}{l}\text { Positive regulation of immune } \\
\text { response }\end{array}$ & 228 & -2.14 & 4.29E-02 \\
\hline GO:0002062 & Chondrocyte differentiation & 45 & -2.12 & 4.70E-02 \\
\hline GO:0006040 & Amino sugar metabolic process & 21 & -2.11 & 4.87E-02 \\
\hline GO:0045061 & Thymic T cell selection & 16 & -2.10 & 4.99E-02 \\
\hline GO:0007229 & $\begin{array}{l}\text { Integrin-mediated signaling } \\
\text { pathway }\end{array}$ & 46 & -2.10 & $4.95 \mathrm{E}-02$ \\
\hline GO:0045309 & $\begin{array}{l}\text { Protein phosphorylated amino } \\
\text { acid binding }\end{array}$ & 21 & -2.10 & $4.89 \mathrm{E}-02$ \\
\hline
\end{tabular}

One mechanism by which PLINs and an increase in LD size may prevent lipid-induced insulin resistance is by sequestering bioactive lipids. Indeed, PLIN5 overexpression increased intramyocellular TAG storage 

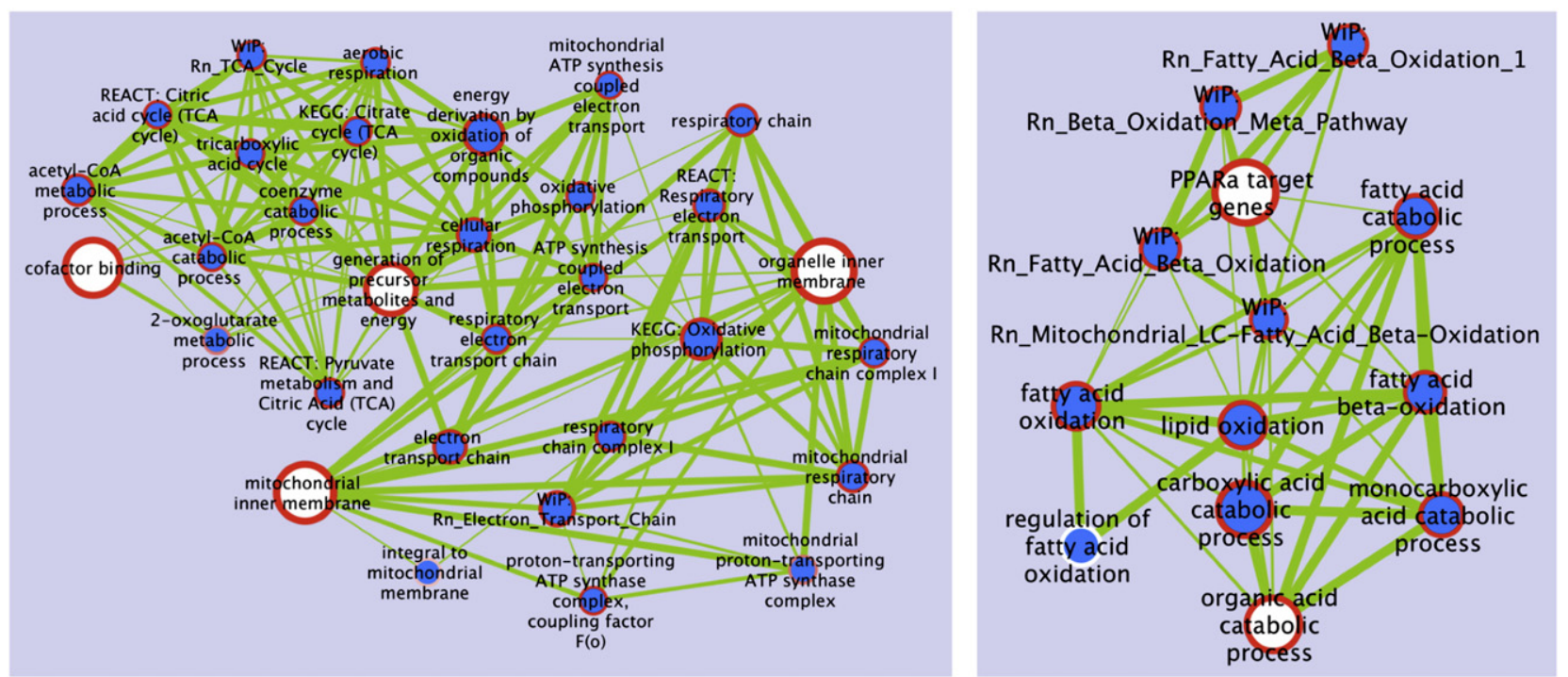

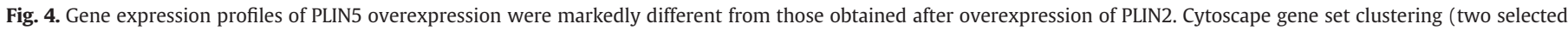

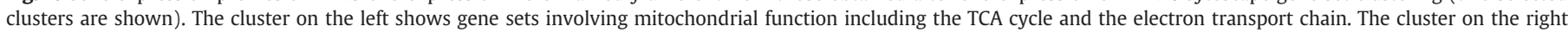

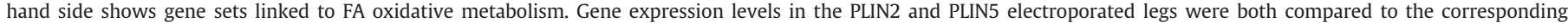

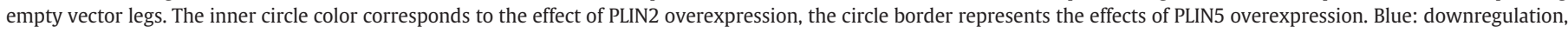
red: upregulation, white: no change. The lines indicate overlap between gene sets. The gene sets included the GO classes, KEGG pathways, REACT, and WiP gene sets.

without affecting the accumulation of the potentially insulin desensitizing and mitotoxic lipid intermediates DAG and acylcarnitines. These effects parallel observations upon PLIN2 overexpression [2], when IMCL content was also augmented while fatty acid intermediates remained unchanged. Thus, both PLIN2 and PLIN5 overexpression augmented neutral TAG accumulation in a manner that did not impede insulin-mediated glucose uptake.

While the effects of PLIN2 and PLIN5 on IMCL content and insulin sensitivity appear alike, marked differences were observed in gene expression profiles. In striking contrast to the effects of PLIN2 overexpression, which results in lowered expression of genes and proteins involved in oxidative metabolism [2], PLIN5 overexpression resulted in a transcriptomic profile representing improved oxidative capacity. Our unbiased microarray approach raised the opportunity to study gene expression patterns across the whole genome. Gene set enrichment analysis revealed an overrepresentation of upregulated genes in a multiple gene sets involved in FA $\beta$-oxidation, the TCA cycle, the electron transport chain and mitochondrion organization. Consistent with our data, ectopic expression of PLIN5 in COS cells increased expression of genes involved in FA oxidation [34]. While short-term (one week) PLIN2 overexpression was beneficial to insulin sensitivity [2], it is anticipated that in the long run, PLIN2 overexpression

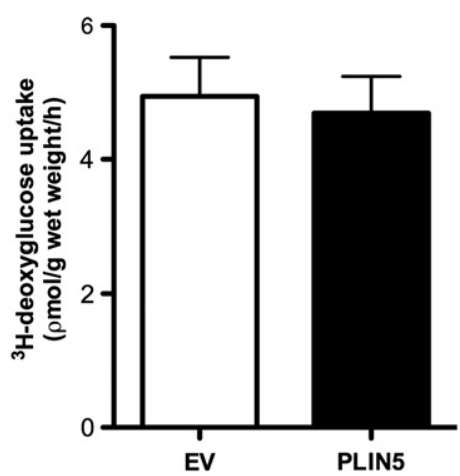

Fig. 5. PLIN5 overexpression-induced intramyocellular lipid accumulation did not affect insulin sensitivity. ${ }^{3} \mathrm{H}$-labeled deoxyglucose uptake $(\rho \mathrm{mol} / \mathrm{g}$ wet weight $/ \mathrm{h})$ in empty vector $(E V)$ and PLIN5-electroporated tibialis anterior muscle $(n=9)$. Error bars represent SEM. may result in a mismatch between lipid storage and oxidative capacity. In contrast, PLIN5 overexpression results in increased IMCL storage paralleled with increased oxidative capacity, observations similar to endurance trained athletes who have high PLIN5 and IMCL levels, are insulin sensitive [28] and are protected against lipid-induced insulin resistance [35].

Since acylcarnitine accumulation has been suggested to reflect an imbalance between $\beta$-oxidation and TCA cycle activity [36], the lack of an induction of acylcarnitine accumulation further confirms that PLIN5 overexpression results in neutral IMCL storage matched with downstream catabolic metabolism. Moreover, genes involved in immune-processes associated with insulin resistance were downregulated upon PLIN5 overexpression. Though, whether increased PLIN5 expression is beneficial in the long term, remains to be investigated.

How PLIN5 overexpression promotes oxidative gene expression is currently unknown. It is however of interest to note that the vast majority of the genes induced is under control of the PPAR-PGC $1 \alpha$ complex. PPAR-PGC1 $\alpha$ mediated gene expression requires fatty acids as ligands. Recent studies in mice lacking the ATGL gene revealed that fatty acids which serve as ligands for PPARs originate from LD lipolysis; lack of ATGL in heart, liver and brown adipose tissue leads to severe reduction of oxidative gene expression [37-39]. It should however be noted that ATGL deficiency in skeletal muscle is not associated with reduced mitochondrial function $[40,41]$. Yet, we previously showed that ectopic overexpression of PLIN1 in cultured myotubes abolished AGTL mediated lipolysis and downregulated oxidative gene expression [42], which could not be rescued by adding exogenous fatty acids to the medium. This indicates that reduced intramyocellular LD lipolysis modulates gene expression by affecting ligand release from the LD. Along the same lines, one may speculate that overexpression of PLIN5 induces a reversed process. In contrast to overexpressing PLIN1 in muscle, overexpressing PLIN5 may promote liberation of fatty acids from the LD as ligands to promote oxidative gene expression and fat oxidative capacity.

Interestingly, PLIN5 appears to have a dual effect on LD lipolysis. Under basal conditions PLIN5 inhibits lipolysis while under stimulated conditions PLIN5 appears to facilitate lipolysis [43-46]. In the present study PLIN5 overexpression resulted in increased ATGL protein content. Thus, a higher availability of both PLIN5 and ATGL may translate into 
increased lipolytic capacity under stimulated conditions and promotes liberation of fatty acids as ligands for the PPAR-PGC1 $\alpha$ complex [37]. With that, PLIN5 overexpression might induce a feed-forward loop, since skeletal muscle PGC1 $\alpha$ activation is known to affect both oxidative capacity and intracellular lipid storage [47-49]. On the other hand, we also observed that overexpression of PLIN5 resulted in a profound increase in LD size and TAG content which could reflect a state of decreased ATGL-mediated lipolysis and hence blunted availability of fatty acids as ligands. Therefore, it cannot be excluded that PLIN5 may activate PPAR/PGC1 via other mechanisms. Based upon subcellular distribution of PLIN5 and its interaction with the mitochondria we previously hypothesized a role for PLIN5 as a chaperone protein shuttling fatty acids towards the mitochondria for oxidation [8]. Similarly, PLIN5 may also be involved in shuttling LD-derived fatty acids towards nuclei to serve as ligands for PPAR/PGC1. In that respect it is of relevance to note that PLIN5 was shown to localize to small, high dense lipid droplets and to be involved in lipid trafficking [29].

Based on previous reports and our current data of improved gene expression of oxidative genes, we propose that PLIN5 is an important player in matching intramyocellular lipid storage capacity with the ability to regulate oxidative gene expression on the one hand and facilitating release of fatty acids from the LD as substrates for mitochondrial oxidation on the other hand.

In summary, PLIN2 and PLIN5 both increase neutral IMCL content without negatively impacting on insulin sensitivity. Interestingly, as opposed to the transcriptomic profile upon PLIN2 overexpression, we here report that overexpression of PLIN5 in skeletal muscle promoted expression of a cluster of genes under control of PPAR $\alpha$ and PGC1 $\alpha$ involved in fatty acid catabolism and mitochondrial oxidation. This suggests a role of PLIN5, either directly or indirectly, in mediating the skeletal muscle oxidative gene expression.

Supplementary data to this article can be found online at http://dx. doi.org/10.1016/j.bbalip.2013.01.007.

\section{Acknowledgements}

Research presented in this article was financially supported by NUTRIM and the graduate school VLAG. A VICI (grant 918.96.618) and a VIDI (grant 917.66.359) for innovative research from the Netherlands Organization for Scientific Research (NWO) support the work of P. Schrauwen and M. Hesselink, respectively. We thank Silvie Timmers, Hazibe Aydeniz and Frits Mattijssen for practical help and technical support.

\section{References}

[1] M. Bosma, S. Kersten, M.K.C. Hesselink, P. Schrauwen, Re-evaluating lipotoxic triggers in skeletal muscle: relating intramyocellular lipid metabolism to insulin sensitivity, Prog. Lipid Res. 51 (2012) 36-49.

[2] M. Bosma, M.K.C. Hesselink, L.M. Sparks, S. Timmers, M.J. Ferraz, F. Mattijssen, D. van Beurden, G. Schaart, M.H. de Baets, F.K. Verheyen, S. Kersten, P. Schrauwen, Perilipin 2 improves insulin sensitivity in skeletal muscle despite elevated intramuscular lipid levels, Diabetes 61 (2012) 2679-2690.

[3] L. Liu, X. Shi, C.S. Choi, G.I. Shulman, K. Klaus, K.S. Nair, G.J. Schwartz, Y. Zhang, I.J Goldberg, Y.H. Yu, Paradoxical coupling of triglyceride synthesis and fatty acid oxidation in skeletal muscle overexpressing DGAT1, Diabetes 58 (2009) 2516-2524.

[4] S. Schenk, J.F. Horowitz, Acute exercise increases triglyceride synthesis in skeletal muscle and prevents fatty acid-induced insulin resistance, J. Clin. Invest. 117 (2007) 1690-1698.

[5] S. Timmers, J. de Vogel-van den Bosch, M.K.C. Hesselink, D. van Beurden, G. Schaart, M.J. Ferraz, M. Losen, P. Martinez-Martinez, M.H. De Baets, J.M.F.G. Aerts, P. Schrauwen, Paradoxical increase in TAG and DAG content parallel the insulin sensitizing effect of unilateral DGAT1 overexpression in rat skeletal muscle, PLoS One 6 (2011) e14503.

[6] M. Beller, K. Thiel, P.J. Thul, H. Jäckle, Lipid droplets: a dynamic organelle moves into focus, FEBS Lett. 584 (2010) 2176-2182.

[7] T.C. Walther, R.V. Farese Jr., The life of lipid droplets, Biochim. Biophys. Acta 1791 (2009) 459-466.

[8] M. Bosma, R. Minnaard, L.M. Sparks, G. Schaart, M. Losen, M.H. De Baets, H. Duimel, S. Kersten, P.E. Bickel, P. Schrauwen, M.K.C. Hesselink, The lipid droplet coat protein perilipin 5 also localizes to muscle mitochondria, Histochem. Cell Biol. 137 (2012) 205-216.
[9] H. Wang, U. Sreenevasan, H. Hu, A. Saladino, B.M. Polster, L.M. Lund, D.W. Gong, W.C. Stanley, C. Sztalryd, Perilipin 5, a lipid droplet associated protein, provides physical and metabolic linkage to mitochondria, J. Lipid Res. 52 (2011) 2159-2168.

[10] C.R. Bruce, C. Brolin, N. Turner, M.E. Cleasby, F.R. van der Leij, G.J. Cooney, E.W. Kraegen, Overexpression of carnitine palmitoyltransferase I in skeletal muscle in vivo increases fatty acid oxidation and reduces triacylglycerol esterification, Am. J. Physiol. Endocrinol. Metab. 292 (2007) E1231-E1237.

[11] C.R. Bruce, A.J. Hoy, N. Turner, M.J. Watt, T.L. Allen, K. Carpenter, G.J. Cooney, M.A Febbraio, E.W. Kraegen, Overexpression of carnitine palmitoyltransferase- 1 in skeletal muscle is sufficient to enhance fatty acid oxidation and improve high fat diet-induced insulin resistance, Diabetes 58 (2009) 550-558.

[12] D.E. James, A.B. Jenkins, E.W. Kraegen, Heterogeneity of insulin action in individual muscles in vivo: euglycemic clamp studies in rats, Am. J. Physiol. Endocrinol. Metab. 248 (1985) E567-E574.

[13] J.-Y. Kim, T.R. Koves, G.-S. Yu, T. Gulick, R.N. Cortright, G.L. Dohm, D.M. Muoio, Evidence of a malonyl-CoA-insensitive carnitine palmitoyltransferase I activity in red skeletal muscle, Am. J. Physiol. Endocrinol. Metab. 282 (2002) E1014-E1022.

[14] H.R. Scholte, Y. Yu, J.D. Ross, I.I. Oosterkamp, A.M.C. Boonman, H.F.M. Busch, Rapid isolation of muscle and heart mitochondria, the lability of oxidative phosphorylation and attempts to stabilize the process in vitro by taurine, carnitine and other compounds, Mol. Cell. Biochem. 174 (1997) 61-66.

[15] B. Ukropcova, M. McNeil, O. Sereda, L de Jonge, H. Xie, G.A. Bray, S.R. Smith, Dynamic changes in fat oxidation in human primary myocytes mirror metabolic characteristics of the donor, J. Clin. Invest. 115 (2005) 1934-1941.

[16] M.D. Abramoff, P.J. Magalhaes, S.J. Ram, Image processing with Imagej, Biophoton. Int. 11 (2004) 36-42.

[17] R. Koopman, G. Schaart, M. Hesselink, Optimisation of oil red O staining permits combination with immunofluorescence and automated quantification of lipids, Histochem. Cell Biol. 116 (2001) 63-68.

[18] D.M. Schwartz, N.E. Wolins, A simple and rapid method to assay triacylglycerol in cells and tissues, J. Lipid Res. 48 (2007) 2514-2520.

[19] N. Van Vlies, L. Tian, H. Overmars, A.H. Bootsma, W. Kulik, R.J. Wanders, P.A. Wood, F.M. Vaz, Characterization of carnitine and fatty acid metabolism in the long-chain acyl-CoA dehydrogenase-deficient mouse, Biochem. J. 387 (2005) 185-193.

[20] R. Gentleman, V. Carey, D. Bates, B. Bolstad, M. Dettling, S. Dudoit, B. Ellis, L. Gautier, Y. Ge, J. Gentry, K. Hornik, T. Hothorn, W. Huber, S. Iacus, R. Irizarry, F. Leisch, C. Li, M. Maechler, A. Rossini, G. Sawitzki, C. Smith, G. Smyth, L. Tierney, J. Yang, J. Zhang, Bioconductor: open software development for computational biology and bioinformatics, Genome Biol. 5 (2004) R80.

[21] A. Subramanian, P. Tamayo, V.K. Mootha, S. Mukherjee, B.L. Ebert, M.A. Gillette, A. Paulovich, S.L. Pomeroy, T.R. Golub, E.S. Lander, J.P. Mesirov, Gene set enrichment analysis: a knowledge-based approach for interpreting genome-wide expression profiles, Proc. Natl. Acad. Sci. 102 (2005) 15545-15550.

[22] C.T. Lopes, M. Franz, F. Kazi, S.L. Donaldson, Q. Morris, G.D. Bader, Cytoscape Web: an interactive web-based network browser, Bioinformatics 26 (2010) 2347-2348.

[23] T.R. Koves, J.R. Ussher, R.C. Noland, D. Slentz, M. Mosedale, O. Ilkayeva, J. Bain, R. Stevens, J.R.B. Dyck, C.B. Newgard, G.D. Lopaschuk, D.M. Muoio, Mitochondrial overload and incomplete fatty acid oxidation contribute to skeletal muscle insulin resistance, Cell Metab. 7 (2008) 45-56.

[24] C. Aguer, M. Foretz, L. Lantier, S. Hebrard, B. Viollet, J. Mercier, M. Kitzmann, Increased FAT/CD36 cycling and lipid accumulation in myotubes derived from obese type 2 diabetic patients, PLoS One 6 (2011) e28981.

[25] B.H. Goodpaster, R. Theriault, S.C. Watkins, D.E. Kelley, Intramuscular lipid content is increased in obesity and decreased by weight loss, Metabolism 49 (2000) 467-472.

[26] D.A. Pan, S. Lillioja, A.D. Kriketos, M.R. Milner, L.A. Baur, C. Bogardus, A.B. Jenkins, L.H. Storlien, Skeletal muscle triglyceride levels are inversely related to insulin action, Diabetes 46 (1997) 983-988.

[27] J.J. Dubé, F. Amati, M. Stefanovic-Racic, F.G.S. Toledo, S.E. Sauers, B.H. Goodpaster, Exercise-induced alterations in intramyocellular lipids and insulin resistance: the athlete's paradox revisited, Am. J. Physiol. Endocrinol. Metab. 294 (2008) E882-E888.

[28] F. Amati, J.J. Dube, E. Alvarez-Carnero, M.M. Edreira, P. Chomentowski, P.M. Coen, G.E. Switzer, P.E. Bickel, M. Stefanovic-Racic, F.G.S. Toledo, B.H. Goodpaster, Skeletal muscle triglycerides, diacylglycerols, and ceramides in insulin resistance: another paradox in endurance-trained athletes? Diabetes 60 (2011) 2588-2597.

[29] S.R. Bartholomew, E.H. Bell, T. Summerfield, L.C. Newman, E.L. Miller, B. Patterson, Z.P. Niday, W.E. Ackerman Iv, J.T. Tansey, Distinct cellular pools of perilipin 5 point to roles in lipid trafficking, Biochim. Biophys. Acta 1821 (2012) 268-278.

[30] M. Imamura, T. Inoguchi, S. Ikuyama, S. Taniguchi, K. Kobayashi, N. Nakashima, H. Nawata, ADRP stimulates lipid accumulation and lipid droplet formation in murine fibroblasts, Am. J. Physiol. Endocrinol. Metab. 283 (2002) E775-E783.

[31] M. Fraenkel, R. Weiss, I. Leizerman, D. Anaby, E. Golomb, G. Leibowitz, N. Kaiser, Scanning electron microscopic analysis of intramyocellular lipid droplets in an animal model of type 2 diabetes, Obesity 16 (2008) 695-699.

[32] J. He, B.H. Goodpaster, D.E. Kelley, Effects of weight loss and physical activity on muscle lipid content and droplet size, Obesity 12 (2004) 761-769.

[33] J.C. Molero, S. Lee, I. Leizerman, A. Chajut, A. Cooper, K. Walder, Effects of rosiglitazone on intramyocellular lipid accumulation in Psammomys obesus, Biochim. Biophys. Acta 1802 (2010) 235-239.

[34] N.E. Wolins, B.K. Quaynor, J.R. Skinner, A. Tzekov, M.A. Croce, M.C. Gropler, V. Varma, A. Yao-Borengasser, N. Rasouli, P.A. Kern, B.N. Finck, P.E. Bickel, OXPAT/PAT-1 is a PPAR-induced lipid droplet protein that promotes fatty acid utilization, Diabetes 55 (2006) 3418-3428.

[35] E. Phielix, R. Meex, D.M. Ouwens, L. Sparks, J. Hoeks, G. Schaart, E. Moonen-Kornips, M.K.C. Hesselink, P. Schrauwen, High oxidative capacity due to chronic exercise training attenuates lipid-induced insulin resistance, Diabetes 62 (2012) 2472-2478. 
[36] D.M. Muoio, Intramuscular triacylglycerol and insulin resistance: guilty as charged or wrongly accused? Biochim. Biophys. Acta 1801 (2009) 281-288.

[37] G. Haemmerle, T. Moustafa, G. Woelkart, S. Buttner, A. Schmidt, T. van de Weijer, M. Hesselink, D. Jaeger, P.C. Kienesberger, K. Zierler, R. Schreiber, T. Eichmann, D. Kolb, P. Kotzbeck, M. Schweiger, M. Kumari, S. Eder, G. Schoiswohl, N. Wongsiriroj, N.M. Pollak, F.P.W. Radner, K. Preiss-Landl, T. Kolbe, T. Rulicke, B. Pieske, M. Trauner, A. Lass, R. Zimmermann, G. Hoefler, S. Cinti, E.E. Kershaw, P. Schrauwen, F. Madeo, B. Mayer, R. Zechner, ATGL-mediated fat catabolism regulates cardiac mitochondrial function via PPAR- $\alpha$ and PGC-1, Nat. Med. 17 (2011) 1076-1085.

[38] E.P. Mottillo, A.E. Bloch, T. Leff, J.G. Granneman, Lipolytic products activate peroxisome proliferator-activated receptor (PPAR) $\alpha$ and $\delta$ in brown adipocytes to match fatty oxidation with supply, J. Biol. Chem. 287 (2012) 25038-25048.

[39] K.T. Ong, M.T. Mashek, S.Y. Bu, A.S. Greenberg, D.G. Mashek, Adipose triglyceride lipase is a major hepatic lipase that regulates triacylglycerol turnover and fatty acid signaling and partitioning, Hepatology 53 (2011) 116-126.

[40] A.J. Hoy, C.R. Bruce, S.M. Turpin, A.J. Morris, M.A. Febbraio, M.J. Watt, Adipose triglyceride lipase-null mice are resistant to high-fat diet-induced insulin resistance despite reduced energy expenditure and ectopic lipid accumulation, Endocrinology 152 (2011) 48-58.

[41] P.M. Nunes, T. van de Weijer, A. Veltien, H. Arnts, M.K.C. Hesselink, J.F.C. Glatz, P. Schrauwen, C.J. Tack, A. Heerschap, Increased intramyocellular lipids but unaltered in vivo mitochondrial oxidative phosphorylation in skeletal muscle of adipose triglyceride lipase-deficient mice, Am. J. Physiol. Endocrinol. Metab. 303 (2012) E71-E81.

[42] T.R. Koves, L.M. Sparks, J.P. Kovalik, M. Mosedale, R. Arumugam, K.L. Debalsi, K. Everingham, L. Thorne, E. Phielix, R.C. Meex, C.L. Kien, M.K. Hesselink, P. Schrauwen, D.M. Muoio, PPAR $\gamma$ coactivator- $1 \alpha$ contributes to exercise-induced regulation of intramuscular lipid droplet programming in mice and humans, J. Lipid Res. 54 (2013) 522-534

[43] J.G. Granneman, H.P.H. Moore, E.P. Mottillo, Z. Zhu, L. Zhou, Interactions of perilipin-5 (PLIN5) with adipose trigylceride lipase (ATGL), J. Biol. Chem. 286 (2011) 5126-5135.

[44] J.G. Granneman, H.P. Moore, E.P. Mottillo, Z. Zhu, Functional interactions between MLDP (LSDP5) and ABHD5 in the control of intracellular lipid accumulation, J. Biol. Chem. 284 (2009) 3049-3057.

[45] K. Kuramoto, T. Okamura, T. Yamaguchi, T.Y. Nakamura, S. Wakabayashi, H. Morinaga, M. Nomura, T. Yanase, K. Otsu, N. Usuda, S. Matsumura, K. Inoue, T. Fushiki, Y. Kojima, T. Hashimoto, F. Sakai, F. Hirose, T. Osumi, Perilipin 5, a lipid droplet-binding protein, protects the heart from oxidative burden by sequestering fatty acid from excessive oxidation, J. Biol. Chem. 287 (2012) 23852-23863.

[46] H. Wang, M. Bell, U. Sreenevasan, H. Hu, J. Liu, K. Dalen, C. Londos, T. Yamaguchi, M.A. Rizzo, R. Coleman, D. Gong, D. Brasaemle, C. Sztalryd, Unique regulation of adipose triglyceride lipase (ATGL) by perilipin 5, a lipid droplet-associated protein, J. Biol. Chem. 286 (2011) 15707-15715.

[47] D.O. Espinoza, L.G. Boros, S. Crunkhorn, H. Gami, M.-E. Patti, Dual modulation of both lipid oxidation and synthesis by peroxisome proliferator-activated receptor- $\gamma$ coactivator- $1 \alpha$ and $-1 \beta$ in cultured myotubes, FASEB J. 24 (2010) 1003-1014.

[48] E. Mormeneo, C. Jimenez-Mallebrera, X. Palomer, V. De Nigris, M. Vázquez-Carrera, A. Orozco, A. Nascimento, J. Colomer, C. Lerín, A.M. Gómez-Foix, PGC-1 $\alpha$ induces mitochondrial and myokine transcriptional programs and lipid droplet and glycogen accumulation in cultured human skeletal muscle cells, PLoS One 7 (2012) e29985.

[49] S. Summermatter, O. Baum, G. Santos, H. Hoppeler, C. Handschin, Peroxisome proliferator-activated receptor $\gamma$ coactivator $1 \alpha$ (PGC- $1 \alpha)$ promotes skeletal muscle lipid refueling in vivo by activating de novo lipogenesis and the pentose phosphate pathway, J. Biol. Chem. 285 (2010) 32793-32800. 